\title{
A Review of HRM Practices and Labor Productivity: Evidence from Libyan Oil Companies
}

\author{
Mohamed Ibrahim Mohamed ${ }^{1}$, Mahazan Abdul Mutalib ${ }^{1}$, Adel M. Abdulaziz ${ }^{2}$, Mikail Ibrahim ${ }^{3} \&$ Nasser \\ Ahmed Nasser Habtoor ${ }^{1}$ \\ ${ }^{1}$ Faculty of Leadership and Management, Universiti Sains Islam, Malaysia \\ ${ }^{2}$ Islamic University of Malaysia, Malaysia \\ ${ }^{3}$ Faculty of Major Languages Studies, Universiti Sains Islam Malaysia, Malaysia \\ Correspondence: Mohamed Ibrahim Mohamed, Faculty of Leadership and Management, Universiti Sains Islam, \\ Malaysia. E-mail: algual85@yahoo.com
}

Received: October 31, 2014 Accepted: November 24, 2014 Online Published: April 2, 2015

doi:10.5539/ass.v11n9p215 URL: http://dx.doi.org/10.5539/ass.v11n9p215

\begin{abstract}
The aim of this study is to review how human resource management (HRM) practice influences labor productivity in oil companies in Libya. This study brought the fact that due to the distinct features of oil companies, common discourses of MRM very often ruled out. In addition, this study focused that HRM is applied at the micro level, which influences the labor productivity in oil companies. Nevertheless, the crucial determinants for fostering labor productivity are not individual level of HRM practice, instead the macroeconomic aspects such as political instability and quality of governance and diplomatic relation. Therefore, this study prescribes a holistic approach, which is that along with micro level of HRM practice and political and macroeconomic stability are crucially important to foster labor productivity.
\end{abstract}

Keywords: oil company, Libya, labor productivity, HRM practice

\section{Introduction}

\subsection{Introduce the Problem}

The manner in which a firm manages its human resources is gradually more recognized as primarily important to carry out of its strategy (Koch \& Macgrath, 1996). Although, there is a strong association between human resource management and firm level performance outcomes in the light of theoretical and normative view, but empirical studies provide less consistency. In the case of Libyan Oil Company, it has been hard to explain labor productivity in the light of modern HRM practice due to so many reasons. Because, the country like Libya possesses very special characteristics, hence modern HRM discourses might not be generally applicable. However, labor productivity is largely influenced by both micro as well as macro aspects of the economy. For instance, the micro aspect may directly influence the labor productivity like, recruitment, training, compensation, motivation, allowance, retirement. Nevertheless, macro aspects also indirectly influence the labor productivity.

For instance, the empirical evidences reveal that oil dominant economies often experience poor labor productivity hence a poor economic growth (Sachs \& Warner, 1995, 1999, 2001; Auty, 2001; Gelb, 1988; Gylfason et al., 1999). Not only Libya, some other resource abundant countries Oil States in the Gulf, or Nigeria, Mexico, Venezuela had not enjoyed a constant economic growth, though; these respective countries have substantial export earnings from oil. On the contrary, the countries relatively with less or no oil resources like Singapore, Taiwan, and Hong Kong have experienced high economic growth. These phenomena can be explained by economic theory of labor productivity. First, due to the high inflow of foreign currency from oil export lends to an appreciation of the real exchange rate. Consequently, the cost of imports increases to some other import oriented industries; hence it may adversely affect the growth by shifting the resources from high-technology and highly skilled sector to low-technology and low skilled sector, which is known as the Dutch diseases (see Krugman, 1987; Corden \& Neary, 1982; Neary \& Van Wijnbergen, 1986). However, there is a debate whether this effect lay on micro level or macro level of the economy. The seminal work of McCormick and Wahba (2000) though present a complete utility maximizing decision process of shifting labor from one to anther industry; however, the study failed to account the fact that an optimum decision must compensate the lost 
production at home, because of potentially high underemployment, an appreciation of the real exchange rate, causing a so-called Dutch disease effect (Acosta et al., 2009; Bourdet \& Falck, 2006; Lartey et al., 2008; Vargas-Silva, 2009). Furthermore, McCormick and Wahba (2000)'s decision process is valid only at the micro level, and it does not consider the impact of foreign earning on domestic labor productivity for the recipient countries at the macro level. The resource curse paradox would be explained with the theory of rent-seeking, where it says that when some private companies lobby the government for loan subsidies, grants or tariff protection. These activities do not create any benefit for society; they just redistribute resources from the taxpayers to the special-interest group. Beside of this, the quality of governance, political and geopolitical issues largely hamper the whole economy, particularly the oil sectors. Easterly and Levine (1997) argued that the quality of governance and natural resources would inversely associate with a sense that abundant natural resources would increase corruption, income inequalities, domestic violence, political unrest and policy weakness in a diversified society. Therefore, governments may follow a hazy manner in sending oil rent for lowering the scope of political maneuvering; hence a certain interest group gets all the benefits (Carneiro, 2007). Consequently, the whole market system in resource abundance economy becomes imbalanced as the benefit from resource goes to the only interest group. The empirical study by Van der Ploeg and Arezki (2008) and Sala-I-Martin and Subramanian (2003) drew a conclusion that natural resources adverse affect on the quality of institutions. Van der Ploeg and Arezki (2008) also showed a significant association between that bad trade policy and bad fiscal policy. Mehlum et al (2006) and Boschini et al. (2007) revealed that natural resources adversely affect the labor productivity in the presence weak institution.

\subsection{Overview of Oil Sector of Libyan Economy}

Libya is one of an important member of the Organization of the Petroleum Exporting Countries (OPEC), and the largest oil reserved country in the Africa. The country is well known about its contributor to the global supply of light, sweet crude oil. Libya's economy depends on the oil sector largely.

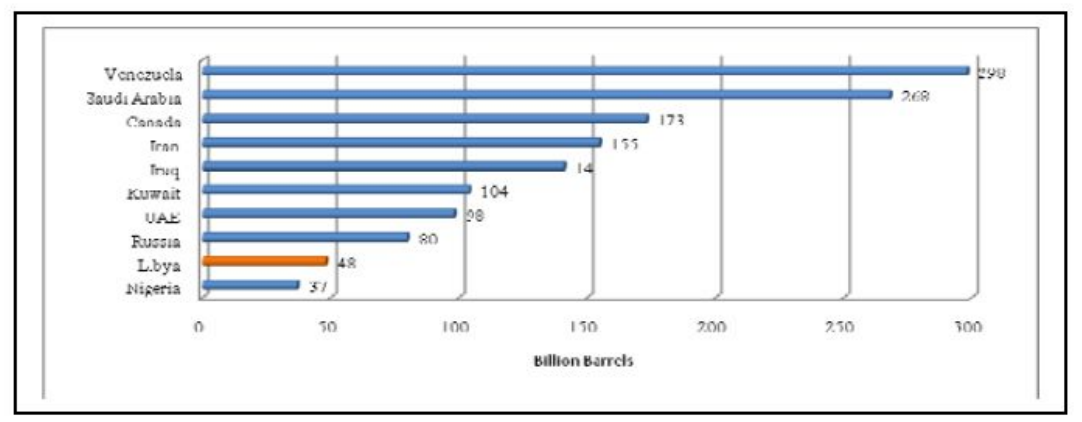

Figure 1. The world's top 10 holders of proven crude oil reserves, 2013 (Billion Barrels), data source, EIA, 2014

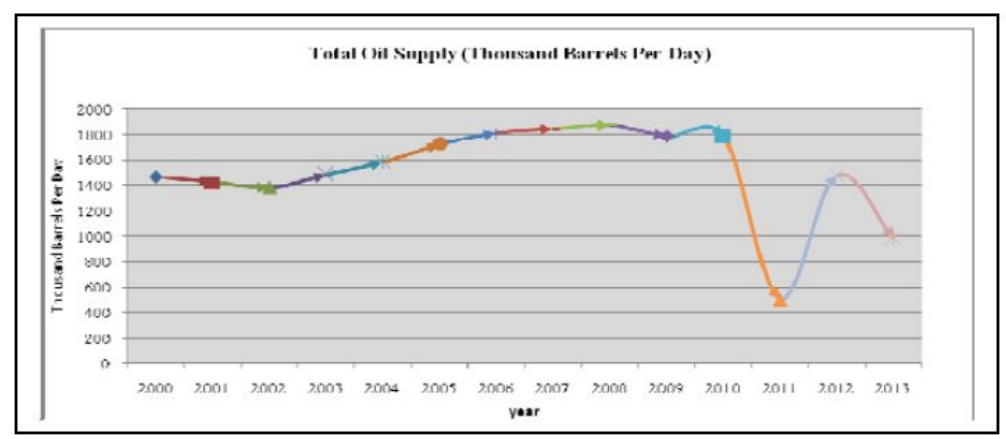

Figure 2. Total oils supply from 2000 to 2013 , data source EIA, 2014

The countries $98 \%$ export earnings from natural gas and oil were $79 \%$ earn only from exporting crude oil (EIA, 2014). Moreover, oil sector accounts about $96 \%$ of total government revenue in 2012. Among the world's top holders of Proven Crude Oil Reserves, Libya stands at $9^{\text {th }}$ position. According to EIA's OPEC Revenues Fact Sheet, the country's export revenue was about at $\$ 4$ billion per month from January to June 2013. The figure 1 clearly shows that the supply of oil has smoothly increased from 2012 to 2009. Although it fell down a little bit 
in 2009 but it sharply increased in 2010. However, as the civil war began in 2011, the oil supply dropped very rapidly. In 2011, the country supplied only about 501 barrels per day; consequently, the GDP fell down by $62 \%$ in the same year (Figure 2).

Regards to the historical background, the Libya gave its first contract of oil extraction to international companies in 1955 (Roudi Fahimi \& Kent, 2007). Later on, marketable oil was exposed in the Libya in 1957 while the first export of oil was taken place in 1961 (Bindra, 2008; Roudi Fahimi \& Kent, 2007). This was the year when the Libya got its first revenue in the form of oil export. In succeeding few years Libya made remarkable progress and in 1970, Libya was the $6^{\text {th }}$ largest country in the world in terms of oil production. The Libyan oil industry has been managed by National Oil Corporation (NOC) since 1968 along with smaller subsidiary companies (Roudi Fahimi \& Kent, 2007). The NOC in the Libya is responsible for the discovery and marketing of oil in local and global markets. Libya has taken attention for investment and export of oil to the European markets. The primary reasons for these are follows; relatively high quality crude oil, low cost oil recovery, nearness to European markets (Outlook, 2013). Foreign investment in the oil industry in the Libya was significantly shrink resulting from the sanctions imposed on Libya particularly, during 1992-1999 (Bindra, 2008). The government of Libya has made attempts to make the country attractive to the foreign investors since the UN sanctions were lifted in 1999 (Roudi Fahimi \& Kent, 2007).

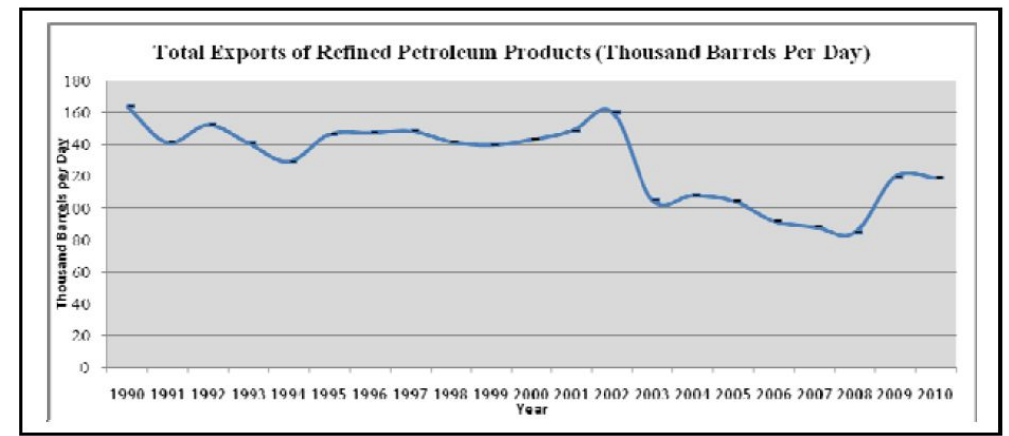

Figure 3. Total exports of refined petroleum products (thousand barrels per day)

The economy of Libya is distinctive in Africa. Some countries of Africa like Algeria, Egypt and Morocco, all have large residents, significant agricultural strength, and well-established industrialized foundations, Libya do not significantly have these resources, however, It has abundant energy resources, especially low-sulfur crude oil as well as natural gas.

Being oil exporting economy, Libya used to export various petroleum products, where the country exported about 162 thousand barrels of refined petroleum per day in 1990 (Figure 3). However, after 1990 this trend oscillated within a very small margin until 1995. Over the period of 1995 to 2001, the rate of export of refined petroleum was on an average 140 thousand barrel per day, but suddenly it sharply increased in 2002. Again, this trend decreased sharply in 2003 and continued a constant rate until 2008. Figure 3 further reports that the export trend turned to rise in 2009 and 2010. After 2010, the civil war started hence, it is assumed it drastically fell down in 2011.

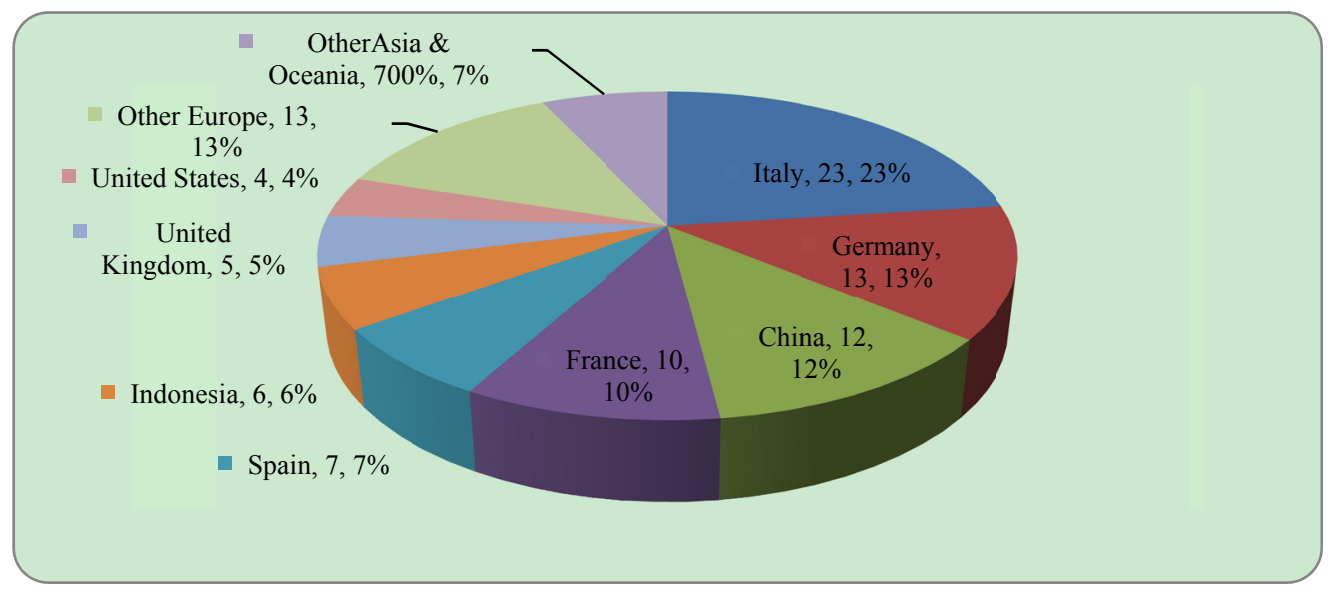

Figure 4. Libya's crude oil exports, by destination, 2012, source EIA, 2014 
Libya usually export the majority of its crude oil to European countries, where Italy is the foremost receiver. The United States started again importing crude oil from Libya in 2004 after embargos were taken off, though the quantity of imports was small. The United States imported 56,000 bbl/d of crude oil from Libya in 2012, which was only about $0.6 \%$ of total U.S. imports during that year. Beside of this, the country used to export $13 \%, 12 \%$, $10 \%, 7 \%, 6 \%$ and 5\% to Germany, China, France, Spain, Indonesia and UK respectively in 2012 (Figure 4).For the period of civil war 2011, crude oil exports dropped to average below 400,000 bbl/d for the year (EIA 2014). However, the country recovered its crude oil exports in 2012 to average roughly 1.25 million bbl/d. However, again crude oil exports fell to averaged around $1.1 \mathrm{million} \mathrm{bbl} / \mathrm{d}$ in the mid of 2013 .

\section{A Brief Overview of Oil Companies in Libya}

\subsection{Introduce Oil Company}

A number of field-operator oil companies have been working in Libya. Table 1 reports the location of oil field, situated region, field operator and their respective lead foreign partners. About 15 field operator companies, this study focus on prime three companies. Table 2 the selected companies are the most important government owned oil companies working under the National Oil Commission (NOC) of Libya. As the leading stakeholders (70 percent of the total oil market) this study focuses on these three companies and further be generalized for the rest of government owned, and private oil companies working in Libya.

Table 1. Libya's oil ports, fields, refineries, and operator

\begin{tabular}{|c|c|c|c|c|c|}
\hline Load Ports & Region & Main fields & Refinery & $\begin{array}{c}\text { Field } \\
\text { operator }\end{array}$ & $\begin{array}{l}\text { Lead foreign } \\
\text { partners }\end{array}$ \\
\hline $\begin{array}{l}\text { Es Sider } \\
\text { (Sidra) }\end{array}$ & Central-east & $\begin{array}{c}\text { Waha, Samah, Dahra, and } \\
\text { Gialo } \\
\text { Mabruk (Mabrouk) }\end{array}$ & \multirow{6}{*}{$\begin{array}{l}\text { RasLanuf; } \\
\text { Tobruk; } \\
\text { Sarir }\end{array}$} & Waha Oil & $\begin{array}{l}\text { ConocoPhillips, } \\
\text { Marathon, Hess }\end{array}$ \\
\hline \multirow[t]{2}{*}{ RasLanuf } & \multirow[t]{2}{*}{ Central-east } & $\begin{array}{c}\text { Mabruk (Mabrouk) } \\
\text { Nafoura } \\
\text { As Sarah/Jakhira b(C96), } \\
\text { Nakhla (C97) }\end{array}$ & & $\begin{array}{c}\text { Mabruk } \\
\text { Agoco } \\
\text { Wintershall }\end{array}$ & $\begin{array}{c}\text { Total } \\
\text { none } \\
\text { Wintershall, } \\
\text { Gazprom }\end{array}$ \\
\hline & & Amal, Naga, Farigh & & Harouje & $\begin{array}{c}\text { Suncor } \\
\text { (PetroCanada) }\end{array}$ \\
\hline \multirow{4}{*}{$\begin{array}{c}\text { Marsa } \\
\text { al-Hariga } \\
\left(\text { Tobruk) }{ }^{2}\right. \\
\text { Zueitina }\end{array}$} & East & $\begin{array}{l}\text { Sarir, Messla, Beda, } \\
\text { Magrid, Hamada }^{3}\end{array}$ & & Agoco & none \\
\hline & Central-east & Abu Attifel, NC-125 & & Mellitah & Eni \\
\hline & & Nakhla (C97) & & Wintershall & $\begin{array}{l}\text { Wintershall, } \\
\text { Gazprom }\end{array}$ \\
\hline & & Intisar Complex and NC74 & & $\begin{array}{l}\text { Zueitina Oil } \\
\text { Company }\end{array}$ & Occidental, OMV \\
\hline \multirow[t]{2}{*}{$\begin{array}{c}\text { Marsa } \\
\text { al-Brega }\end{array}$} & Central-east & $\begin{array}{c}\text { Brega (Nafoura/Augila } \\
\text { complex) }\end{array}$ & $\begin{array}{c}\text { Marsa } \\
\text { al-Brega }\end{array}$ & Agoco & none \\
\hline & & $\begin{array}{l}\text { Nasser (Zelten), Raguba, } \\
\text { Lehib (DorMarada) }\end{array}$ & & Sirte Oil & none \\
\hline Mellitah & West & $\begin{array}{l}\text { El Feel (Elephant), oil and } \\
\text { condensate from Wafa and } \\
\text { Bahr Essalam gas fields }\end{array}$ & & Mellitah & Eni \\
\hline $\begin{array}{l}\text { Zawiya or } \\
\text { Zawia } \\
\text { (Tripoli) }\end{array}$ & West & $\begin{array}{l}\text { El Sharara (NC-115) and } \\
\text { NC-186 fields }\end{array}$ & Zawiya & Akakus & $\begin{array}{l}\text { Repsol, Total, } \\
\text { OMV }\end{array}$ \\
\hline Bouri & West & Bouri (offshore) & & Mellitah & Eni \\
\hline $\begin{array}{l}\text { Farwah } \\
\text { (Al-Jurf) }\end{array}$ & West & Al-Jurf (offshore) & & Mabruk & Total \\
\hline
\end{tabular}

\subsection{Waha Oil Company (WOC)}

Waha is one of the prominent oil company in Libya, which was initiated 1956. The company is publicly owned, where 3200 employees are working there. The company's headquarter is located in Tripoli. The Waha consortium consists of American firms ConocoPhillips, Marathon, and Hess, in partnership with NOC. Waha has 
a total production capacity about more than 350 thousand barrels per day. However, Waha is divided among a number of loosely defined fields those are often referred by different names. The main fields of Waha Oil Company are Waha, Gialo, Dahra, and Samah those are substantially large. The fields operated by Waha are located in the Sirte basin, which was shut down during the civil war but it restarted, in late 2011. However, the production was highly hampered due to labor strikes and infrastructural damage, particularly to its export outlet at the Es Sider terminal (EIA, 2014). Nevertheless, the production was raised rapidly to around 300 thousand $\mathrm{bbl} / \mathrm{d}$.

\subsection{Arabian Gulf Oil Company (AGOCO)}

AGOCO is another prominent oil company in Libya, commenced in 1979. Currently, the company is consisted with 2400 full time employees. The headquarter of the company is located in Benghazi. AGOCO works in the eastern area of Cyrenaica, which was a key center of confrontation to Qadhafi. The outline of this Benghazi-based NOC supplementary amplified significantly following its relatively early defection from the regime in support of the insurgency. AGOCO stated that they had at least 400 thousand bbl/d of pre-crisis oil production capacity, which is the largest of any foreign or domestic company in Libya. Its most significant fields are located at Sarir and Messla(approximately 100 thousand $\mathrm{bbl} / \mathrm{d}$ ) in the Sirte basin. It is reported that there were irregular operation of AGOCO production during the conflict, while almost all other companies were shut down, but the firm began to reinstate production in earnest in September 2011. The volume of oil production was about 350 thousand $\mathrm{bbl} / \mathrm{d}$ in May 2012. Obstruction to full production includes technical problems associated with pumps and power supplies and a small, short-lived, but symbolically considerable interruption to production in May 2012 when company headquarters was blocked by protesters.

\subsection{Sirte Oil Company (SOC)}

Sirte is another government owned Oil Company, which was stated in 1981. Currently about 6652 employees are working. The headquarter of the company is located in Brega. Similar with AGOCO, Sirte Oil Company is a NOC subsidiary that works in the eastern Sirte basin. It also works the Al-Ruqhubh and other fields, with a total extraction capacity of at least 100 thousand barrels per day.

Table 2. Description of selected government oil companies

\begin{tabular}{cccc}
\hline Company & Waha oil company & The Arabian Gulf Oil Company & Sirte Oil Company \\
\hline Industry & Petroleum & Petroleum & Petroleum \\
Products & Oil and Gas & Oil and Gas & Oil and Gas \\
Employee & 3200 & 2400 & 6652 \\
Status & Government owned & Government owned & Government owned \\
Year of establishment & 1956 & 1979 & 1981 \\
Headquarter & Tripoli & Benghazi & Brega \\
\hline
\end{tabular}

Source: www.eia.doe.org

\section{HRM Practices and Labor Productivity}

\subsection{Introduce HRM Practices and Labor Productivity}

Human resource management has attracted a huge attention and also has emerged important discussion among various stockholders such as academicians and practitioners (Bowen \& Ostroff, 2004). Although HRM is a buzz word however, there is no single universally accepted definition of the concept (Ruël \& Bondarouk, 2014). 'HRM is a planned and rational scheme for the management of population functioning in an organization that alone and together puts in the effort for the accomplishment of organizational objectives'(Legge, 1989).

HRM is defined as a methodological approach to develop a formal structure in an organization to guarantee proper recruitment \& selection, training \& development, performance appraisal, career planning system, employee participation, and compensation system for efficient and effective utilization of skilled \& motivated human resource to achieve organizational strategic and operational objectives (Masood, 2010). The impact of HR practices on organizational performance has been an important area of HRM research. The researchers has widely focused on the effect of Human Resource Management practices on organizational productivity and financial performance (Choi, 2011). Success in today's world business is lying behind the benefits and scales of operations and scale of economies. Access to higher productivity level is only possible when competent human resource with proper attitude, skills and knowledge are selected on the basis of organizational requirements. Thus is this context, HR practices can work with motivation towards organizational performance. Although in 
most of the developing countries, the main hindrance of organizational growth and profitability is either no or negligible use of professional HRM practices, but, the struggle is continuing to find the best way to use these practices optimally. Pakistan has been focusing on industrial growth for the last few decades. As a result, the organizations from different industries are performing a momentous role in the economic development of the country. Despite their economic importance, different organizations suffer from a variety of structural and institutional weaknesses, which have constrained their ability to take full advantage of rapidly advancing process of globalization and HRM practices. Following are the selected components of HRM practices which help organizations to achieve their goals such increase in productivity, growth, financial and non-financial benefits.

There is a rising agreement among the researchers that organizational human resource policies can improve labor Productivity and organizational goals like productivity and sale. Empirical studies largely focuses on individual HRM practices to achieve organizational goals (Huselid, 1995). Numerous literature support that HRM practices can increase productivity and Productivity of the employees and hence total productivity of the firm (Huselid, 1995; Koch \& McGRATH, 1996). The literature shows various degrees of influence of different HRM practices on labor Productivity. For example training has an immediate effect on the labor Productivity (Koch \& McGRATH, 1996), while information sharing has a positive impact of the productivity but through secondary channels (Delaney \& Huselid, 1996). Studies which support the positive influence of HR practices and organizational outcomes are numerous and significant across the Countries (Bloom \& Reenen, 2011; Delaney \& Huselid, 1996; Park \& Shaw, 2013). Although many studies have reported a positive link between different HRM practices and objective of firm such as increase in productivity, revenue and sale while there are researchers (Ruël \& Bondarouk, 2014; Tharenou, Saks, \& Moore, 2007; Woodrow \& Guest, 2014) who are looking critically to the practice of HRM and the labor Productivity. One of the causes about the disagreement among the researchers may be the methodological concerns. Moreover, the lack of a widely accepted measure of standard HRM practices makes it difficult to compare findings across studies. Although, the literature about HRM practices can be divided into optimistic and pessimistic results however, the optimistic HRM practices to enhance the Productivity of employees and organizational outcome is more dominant (Delaney \& Huselid, 1996; Huselid, 1995).

Human Resource (HR) practices at the oil sector adversely affecting the labor productivity and hence ultimate organizational objective such as optimal extraction of oil (Bindra, 2008). Similarly, the recruitment of employees in the oil sector does not show standard human resource recruitment practices which become hurdles in optimal productivity of employees. Investigating perception of the employees' about thee HR practices including staff selectivity, hire and fire, motivation, decentralized decision making, internal labor market etc., and its impact of on the organizational goal (which is in this case is perception of labor productivity) in the Libyan energy sector will reveal pros and cons of the sector which in turn will help to build skills especially in its core activities in the production of oil that contributes to over $90 \%$ of countries income.

A reduction in oil extraction is not solely an HR phenomenon. There are may be other reasons of low oil production such as political instability, macro-economic factors, technological factors, and reputation of the country in international community, resource curse, economic stability of the country, Investment opportunities etc. The investigation of the outcome of the oil companies in Libya is obviously not possible or desirable at this stage. The gap, in the literature about HR practices and organizational outcome (in this case in the form of labor productivity) and the evidence of few studies shows lacking of proper HR practices resulting in lower productivity through different channels is a motivation for this study.

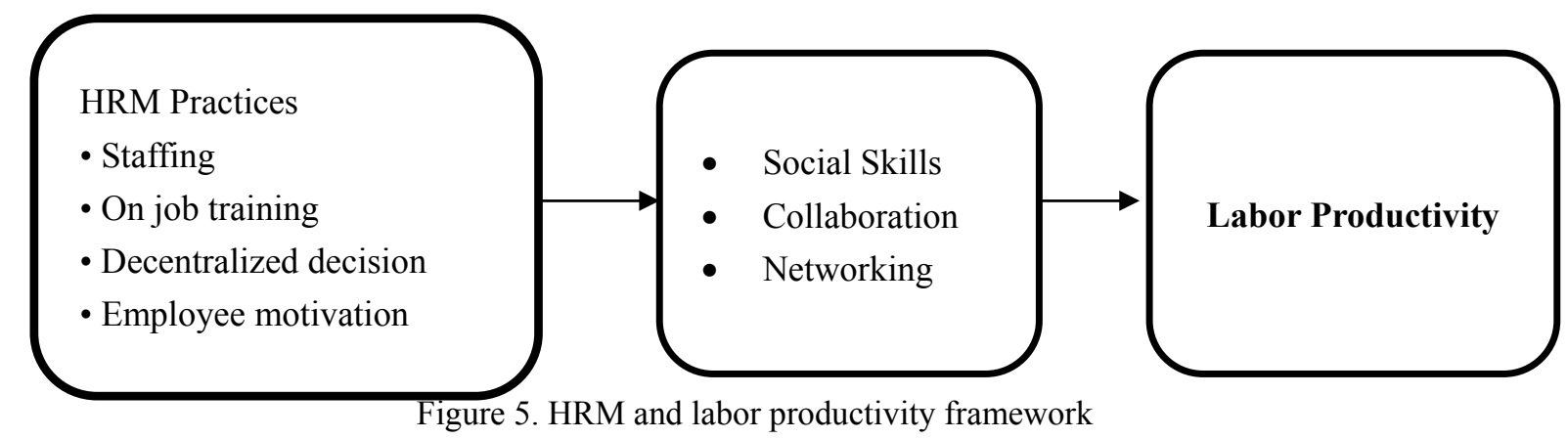

Human resource practices is a wide term used to show all those practice as a system that attracts, develops, motivates, and retains employees to ensure the effective implementation and the survival of the organization and 
its members. HRM practices is also conceptualized as a set of on the inside reliable strategies and practices designed and applied to ensure that a firm's human capital add to the achievement of its business objectives (Delery, 1998). This study using four important aspects of HR practices such as staff selection, on job training, decentralized decision making and employees' motivation.

\subsection{Staff Selection}

Staff selection is an imperative procedure for an institute which settles on the recruitments of workers in respect of particular job requirements (Iles, 1998). More specifically, staff selection is the procedure of making a rational choice among the potential candidates, those who are competitive accomplishing the tasks. This procedure of selecting staffs largely depends on whether the job requirements and candidates skills, qualifications and their willingness blend or not for the vacant position (Iles, 1998). A vigilant staffing procedure can bring an equilibrium between what is required (organizational requirements) and what is offered (candidate abilities) to meet organizational needs (Martín-Alcázar, Romero-Fernández, \& Sánchez-Gardey, 2008). Staff selection is one of the prime components of HR practice, which has direct and indirect influence on organizational outcome such as productivity and sale (Huselid, Becker, \& Beatty, 2005). Organizations can utilize different HR practices to improve worker's skills, which aim to foster labor productivity. An ample of study reveals that a sophisticated staff selection is positively associated with labor productivity and thus the performance of the organization (Huselid \& Becker, 1996; Huselid et al., 2005).

Katou and Budhwar (2007) stated that employees selection and organizational targets such as mounting overall productivity by improving labor productivity and profit margin of firms, were strongly connected with each other. Katou (2008) conducted a study measuring impact of HRM on organizational performance in the context of Greece. The researcher collected data from 178 organizations using a questionnaire survey in the Greek manufacturing sector, and analyzed the data by using 'structural equation modeling' approach. The results pointed out that the association between HRM practice such as staffing and organizational performance is somewhat mediated through HRM outcome such as skill.

\subsection{Job Training}

Training would be explained as a set of intervention that is intended to improve the determinants of individual performance (De Grip \& Sauermann, 2013). In order to foster the organizational output the function of training is crucial. Training augments the productive capacity of employees and thus helps them attaining their organizational objectives. It is also very conducive for workers to reduce their worries during the working hours and help in plummeting the turnover rate (Sahinidis \& Bouris, 2008). The bigger the mismatching between the required skills and employee's actual skills, leads the greater the lack of job satisfaction of the employees and finally less productivity. An organization is able to progress the quality of existing employees by conducting comprehensive training and development activities after recruitment. A substantial evidence indicates that investments in training make beneficial organizational outcomes such as increasing in labor productivity and hence optimal achievement of organizational goals (Bartel, 2004). Training is frequently considered as a tool to foster the workers knowledge, skills and abilities in an organization. Existing literature reveals that training interventions progress the labor performance (Goldsmith, Veum, \& Darity, 2001). Saks (1995) exhibited that conducting on job training improved worker's productivity. Similarly Thang, Buyens, and Leuven (2008) found that training significantly foster knowledge, skills, abilities, attitudes, and behavior of employees that eventually get better outstanding financial and non-financial performance of the organizations. However, training, skills, and education of a worker and their productivity have a two-way relationship. In the case of when worker's skills and education requirements mismatch each other, that lead to reduce the productivity (Storey, 2004; Thang et al., 2008; Tharenou et al., 2007). Many studies have reveled regarding the utility of training, which explained the relationship between training and labor productivity and hence organizational outcomes (Betcherman, Leckie, McMullen, \& Network, 1998; De Grip \& Sauermann, 2013). A relevant training boost an employee's ability to execute the given job-related tasks.Tharenou et al. (2007) talked about the relationship between training and organizational-level outcomes by evaluating the outcome of previous studies that have investigated the relationship between training and human resource, performance, and financial outcomes. The research highlighted that 67 studies suggest that training is positively associated to human resource outcomes and organizational performance such labor productivity but it is very weakly related to financial outcomes. The association between training and firm performance may be arbitrated by employee attitudes and skills. Finally, training found to be more strongly associated with organizational outcomes when it is harmonized with key appropriate factors such as organization capital intensity and business strategy. 


\subsection{Decentralized Decision Making}

Decentralization refers a decision making responsibility, which is approved by the organization constitution, meaning that top management to middle and lower-level mangers within the organization, allowing top management to focus more on major decisions (Zabojnik, 2002). A prominent study of Bloom, Sadun, and Van Reenen (2012), who conducted the first survey on the decentralization process in 4000 different firms across the world, such as United States, Europe and Asia. They established the fact that decentralization improves collective productivity of the firms. They give the essence that there are many aspects those allow the decentralization to improve organizational outcome. Decentralization is crucial for the shaping of large firms, since for a CEO is unable to go through each small affairs of the company. Most importantly, it can be said that decentralization is connected to firm productivity because the CEO of a more centralized firm does not make all decisions within small period of time. Moreover, decentralizing decision-making can obtain the organizational benefit while it is required to make decision immediately (Richardson et al., 2002). The literature investigative the correlation of decentralization to organizational performance is both scarce and vague. (Richardson et al., 2002) examined decentralization's influence on organizational performance in a sample of behavioral healthcare treatment centers. They pointed out that decentralization has a direct correlation with labor productivity and overall organizational performance (both financial and non-financial).

\subsection{Motivation}

Motivation can be defined as a process of enhancing labor productivity by providing effective compensation and reward (Abozed, Melaine, \& Saci, 2009; Kanfer, Chen, \& Pritchard, 2012). Rewards and Returns form employees' behavior and performance output. Surely, monetary and other form of incentive improves employee competencies, thus organizational performance. Mathis (2004) recommended that a fair, transparent, and competitive reward and compensation system foster the retention of talents. Likewise, Dreher \& Dougherty (2005) revealed that a reward-based approach plays a role as the driving factor of team and individual performance in organizations while Chiu and Xihua (2008) stated that worker's benefits and compensation significantly influence organizational outcomes such labor productivity and organizational performance. HR practices improve the productivity of workers while motivation retains them within the organization (Chiu \& Xihua, 2008).

In the light of the above discussion, it can be said that rewards and compensations foster retention of employees with the best talents for labor competence within the organization

\subsection{Labor Productivity}

Labor productivity (LP) is the ratio of output to the input of labor. Very often, it is calculated as the amount of output produced per hour worked (Thomas et al., 1990). Mathematically this can be measured by the ratio of the amount of outputs produced to given by the level of inputs used. This implies the measure of the productivity of firms, industries and even the economy as a whole. The essence of productivity is in fact a supply-side measure, that is, it pertains the technical production relationships between inputs and outputs (Inklaar \& Timmer, 2013).

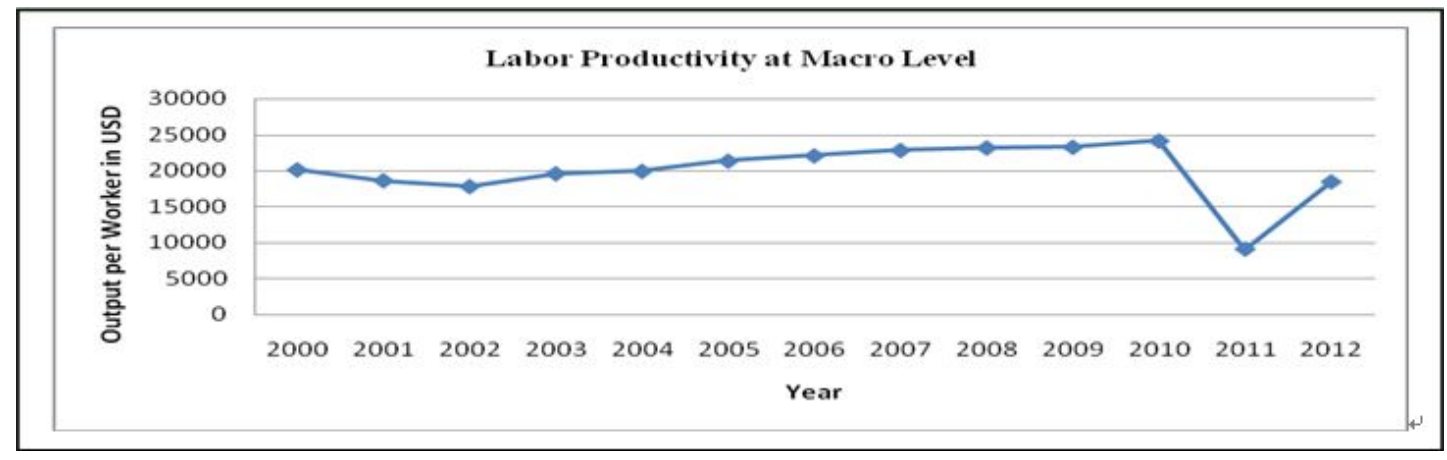

Figure 5. Labor productivity at macro level, data source: WDI 2014

However, since this study follows a review study, therefore by using secondary data, we tried to measure the labor productivity as a whole economy of Libya. We estimated labor productivity simply dividing GDP constant by the total labor force. The Figure 5 clearly illustrates that from 2000 to 2010 , the labor productivity was smoothly increasing. Nevertheless, it drastically dropped in 2011 due to the civil war. 


\section{Conclusion}

This review study on HRM practice and labor productivity highlights several important aspects. Firstly, oil companies possess distinct features hence a common discourse of human resources management may not generally applied. Secondly, based existing literature, the above discussion of the paper clearly focused HRM practice at micro level might influence the labor productivity in oil companies. However, the focal determinants for fostering labor productivity are not individual level of HRM practice, instead the macro aspects. Thirdly, the macro aspects such as political instability and quality of governance significantly influence the labor productivity. Therefore, this study draws a conclusion that micro level of HRM practice and political and macroeconomic stability are crucially important to foster labor productivity. This review study enables us to provide several recommendations in terms of HRM practices in the oil companies in Libya. Primarily, the companies should recruit international competitive human resources by ensuring transparency. In addition, the compensation also should be competitive. In order to bring efficiency, there should the labor division, according to the skills. Since, various macroeconomic and government policy aspects affect labor productivity, hence the companies should be apart from any sort of corruption.

\section{Reference}

Abozed, M., Melaine, Y., \& Saci, K. (2009). The Influence of Work Environmental Factors on Motivation to Transfer Management Training: Case Study of the Libyan Oil Industry. Paper presented at the 4th Annual Conference Liverpool BEAN.

Acosta, P. A., Lartey, E. K., \& Mandelman, F. S. (2009). Remittances and the Dutch disease. Journal of international economics, 79(1), 102-116. http://dx.doi.org/10.1016/j.jinteco.2009.06.007

Arezki, R., \& Van der Ploeg, F. (2011). Do natural resources depress income per capita? Review of Development Economics, 15(3), 504-521. http://dx.doi.org/10.1111/j.1467-9361.2011.00623.x

Baldwin, R. (1987). Politically realistic objective functions and trade policy PROFs and tariffs. Economics Letters, 24(3), 287-290. http://dx.doi.org/10.1016/0165-1765(87)90132-7

Bartel, A. P. (2004). Human resource management and organizational performance: Evidence from retail banking. Industrial and Labor Relations Review, 181-203. http://dx.doi.org/10.2307/4126616

Betcherman, G., Leckie, N., McMullen, K. E., \& Network, Canadian Policy Research Networks. Work. (1998). Barriers to employer-sponsored training in Canada: $C P R N=R C R P P$.

Bindra, N. H., \& Lahmar, S. P. (2008). Human resource planning \& control for energy industry in Libya: Meeting the challenge.

Bloom, N., \& Reenen, J. V. (2011). Human resource management and productivity. Handbook of labor economics, 4, 1697-1767. http://dx.doi.org/10.1016/S0169-7218(11)02417-8

Boschini, A. D., Pettersson, J., \& Roine, J. (2007). Resource Curse or Not: A Question of Appropriability. The Scandinavian Journal of Economics, 109(3), 593-617. http://dx.doi.org/10.1111/j.1467-9442.2007.00509.x

Bourdet, Y., \& Falck, H. (2006). Emigrants' remittances and Dutch disease in Cape Verde. International Economic Journal, 20(3), 267-284. http://dx.doi.org/10.1080/10168730600879323

Bowen, D. E., \& Ostroff, C. (2004). Understanding HRM-firm performance linkages: The role of the "strength" of the HRM system. Academy of management review, 29(2), 203-221.

Choi, M. (2011). Employees' attitudes toward organizational change: A literature review. Human Resource Management, 50(4), 479-500. http://dx.doi.org/10.1002/hrm.20434

Corden, W. M., \& Neary, J. P. (1982). Booming sector and de-industrialisation in a small open economy. The economic journal, 825-848. http://dx.doi.org/10.2307/2232670

De Grip, A., \& Sauermann, J. (2013). The effect of training on productivity: The transfer of on-the-job training from the perspective of economics. Educational Research Review, 8, 28-36. http://dx.doi.org/10.1016/ j.edurev.2012.05.005

Delaney, J. T., \& Huselid, M. A. (1996). The impact of human resource management practices on perceptions of organizational performance. Academy of Management journal, 39(4), 949-969. http://dx.doi.org/10. $2307 / 256718$

Delery, J. E., \& Shaw, J. D. (2001). The strategic management of people in work organizations: Review, synthesis, and extension. Research in personnel and human resources management, 20, 165-197. 
http://dx.doi.org/10.1016/S0742-7301(01)20003-6

Delery, J. E. (1998). Issues of fit in strategic human resource management: Implications for research. Human resource management review, 8(3), 289-309. http://dx.doi.org/10.1016/S1053-4822(98)90006-7

Easterly, W., \& Levine, R. (1997). Africa's growth tragedy: policies and ethnic divisions. The Quarterly Journal of Economics, 1203-1250. http://dx.doi.org/10.1162/003355300555466

Gelb, A. H. (1988). Oil windfalls: Blessing or curse? Oxford University Press.

Goldsmith, A. H, Veum, J. R., \& Darity, W. (2001). Motivation and labor market outcomes. Research in labor economics, 19, 109-146. http://dx.doi.org/10.1016/S0147-9121(00)19006-5

Gylfason, T., Herbertsson, T. T., \& Zoega, G. (1999).A mixed blessing. Macroeconomic dynamics, 3(02), 204-225. http://dx.doi.org/10.1017/S1365100599011049

Huselid, M. A. (1995). The impact of human resource management practices on turnover, productivity, and corporate financial performance. Academy of management journal, 38(3), 635-672. http://dx.doi.org/10.2307/256741

Huselid, M. A., Becker, B. E., \& Beatty, R. W. (2005). The workforce scorecard: Managing human capital to execute strategy. Harvard Business Press.

Iles, P. (1998). Managing staff selection and assessment. McGraw-Hill International.

Kanfer, R., Chen, G., \& Pritchard, R. D. (2012). Work motivation: past, present and future. Routledge.

Katou, A. A. (2008). Measuring the impact of HRM on organizational performance. Journal of Industrial Engineering and Management, 1(2), 119-142. http://dx.doi.org/10.3926/jiem.2008.v1n2.p119-142

Katou, A. A., \& Budhwar, P. S. (2007). The effect of human resource management policies on organizational performance in Greek manufacturing firms. Thunderbird international business review, 49(1), 1-35. http://dx.doi.org/10.1002/tie.20129

Koch, M. J., \& McGRATH, R. I. T. A. (1996). Improving labor productivity: Human resource management policies do matter. Strategic Management Journal, 17(5), 335-354. http://dx.doi.org/10.1002/(SICI)10970266(199605)17:5<335::AID-SMJ814>3.0.CO;2-R

Legge, K. (1989). Human resource management: a critical analysis. New perspectives on human resource management, 19-40.

Martín - Alcázar, F., Romero - Fernández, P. M., \& Sánchez - Gardey, G. (2008). Human Resource Management as a Field of Research. British Journal of Management, 19(2), 103-119. http://dx.doi.org/10.1111/j.1467-8551.2007.00540.x

Masood, T. (2010). Impact of Human Resource Management (HRM) Practices on Organizational Performance: A Mediating Role of Employee Performance. Mohammad Ali Jinnah University.

McCormick, B., \& Wahba, J. (2000). Overseas employment and remittances to a dual economy. The Economic Journal, 110(463), 509-534. http://dx.doi.org/10.1111/1468-0297.00535

Mehlum, H., Moene, K., \& Torvik, R. (2006). Institutions and the resource curse. The Economic Journal, 116(508), 1-20. http://dx.doi.org/10.1111/j.1468-0297.2006.01045.x

Morin, P., Hamad, B., Sapaly, G., Carneiro Rocha, M. G., Pries de Oliveira, P. G., Gonzalez, W. A., ... Essayem, N. (2007). Transesterification of rapeseed oil with ethanol: I. Catalysis with homogeneous Kegginheteropolyacids. Applied Catalysis A: General, 330, 69-76. http://dx.doi.org/10.1016/j.apcata. 2007.07.011

Neary, J. P., \& Van Wijnbergen, S. (1986). Natural resources and the macroeconomy.

Outlook, Annual Energy. (2013). Energy Information Administration. United States.

Park, T.-Y., \& Shaw, J. D. (2013). Turnover rates and organizational performance: A meta-analysis. Journal of Applied Psychology, 98(2), 268. http://dx.doi.org/10.1037/a0030723

Richardson, H. A., Vandenberg, R. J., Blum, T. C., \& Roman, P. M. (2002). Does Decentralization Make a Difference for the Organization? An Examination of the Boundary Conditions Circumbscribing Decentralized Decision-Making and Organizational Financial Performance. Journal of Management, 28(2), 217-244. http://dx.doi.org/10.1177/014920630202800205

RoudiFahimi, F., \& Kent, M. M. (2007). Challenges and Opportunities--the Population of the Middle East and 
North Africa. Population Reference Bureau.

Ruël, H., \& Bondarouk, T. (2014). e-HRM Research and Practice: Facing the Challenges Ahead Handbook of Strategic e-Business Management (pp. 633-653). Springer.

Sachs, J. D., \& Warner, A. M. (1999). The big push, natural resource booms and growth. Journal of development economics, 59(1), 43-76. http://dx.doi.org/10.1016/S0304-3878(99)00005-X

Sachs, J. D., \& Warner, A. M. (2001). The curse of natural resources. European economic review, 45(4), 827-838. http://dx.doi.org/10.1016/S0014-2921(01)00125-8

Sachs, J. D., Warner, A., Åslund, A., \& Fischer, S. (1995). Economic reform and the process of global integration. Brookings papers on economic activity, 1-118. http://dx.doi.org/10.2307/2534573

Sahinidis, A. G., \&Bouris, J. (2008). Employee perceived training effectiveness relationship to employee attitudes. Journal of European Industrial Training, 32(1), 63-76. http://dx.doi.org/10.1108/030905908 10846575

Sala-i-Martin, X., \& Subramanian, A. (2003). Addressing the natural resource curse: An illustration from Nigeria (No. w9804). National Bureau of Economic Research. http://dx.doi.org/10.3386/w9804

Storey, D. J. (2004). Exploring the link, among small firms, between management training and firm performance: a comparison between the UK and other OECD countries. The International Journal of Human Resource Management, 15(1), 112-130. http://dx.doi.org/10.1080/0958519032000157375

Thang, N. N., Buyens, D., \& Leuven, V. (2008). Training, organizational strategy, and firm performance. The Business Review, Cambridge, 11(2), 176-183.

Tharenou, P., Saks, A. M., \& Moore, C. (2007). A review and critique of research on training and organizational-level outcomes. Human Resource Management Review, 17(3), 251-273. http://dx.doi.org/10.1016/j.hrmr.2007.07.004

Thomas, H. R., Maloney, W. F., Horner, R., Malcolm, W., Smith, G. R., Handa, V. K., \& Sanders, S. R. (1990). Modeling construction labor productivity. Journal of Construction Engineering and Management, 116(4), 705-726. http://dx.doi.org/10.1061/(ASCE)0733-9364(1990)116:4(705)

Vargas-Silva, C. (2009). The tale of three amigos: Remittances, exchange rates, and money demand in Mexico. Review of Development Economics, 13(1), 1-14. http://dx.doi.org/10.1111/j.1467-9361.2008.00468.x

Woodrow, C., \& Guest, D. E. (2014). When good HR gets bad results: exploring the challenge of HR implementation in the case of workplace bullying. Human Resource Management Journal, 24(1), 38-56. http://dx.doi.org/10.1111/1748-8583.12021

Zabojnik, J. (2002). Centralized and decentralized decision making in organizations. Journal of Labor Economics, 20(1), 1-22. http://dx.doi.org/10.1086/323929

\section{Copyrights}

Copyright for this article is retained by the author(s), with first publication rights granted to the journal.

This is an open-access article distributed under the terms and conditions of the Creative Commons Attribution license (http://creativecommons.org/licenses/by/3.0/). 